\author{
コミュニケーションとタスクの実態調査の分析と \\ インフォーマルコミュニケーションを予測する行動シミュレーションヘの応用 \\ 知的生産性向上を目指した執務空間に㧍ける \\ コミュニケーションおよび環境要素に関する実態調査(その 2 )
}

\title{
APPLICATION TO HUMAN BEHAVIOR SIMULATION TO MAKE PREDICTION OF INFORMAL COMMUNICATION BASED ON ANALYSIS OF SURVEY OF COMMUNICATION AND TASK
}

Field survey on communication and workplace environment in an office which is aimed at improving workplace productivity (Part2)

沼中秀一*, 高 橋 祐 樹*, 杉崎 奈緒子***, 菊池卓 郎*, 加藤信 介**, 天野 健太郎*, 谷 英明*, 高橋 幹 雄*

\section{Shuichi NUMANAKA, Hiroki TAKAHASHI, Naoko SUGISAKI, Takuro KIKUCHI, Shinsuke KATO, Kentaro AMANO, Hideaki TANI and Mikio TAKAHASHI}

\begin{abstract}
The purpose of this study is to obtain a knowledge contributing to the study of the workplace productivity improvement by using analysis of survey and human behavior simulation. This study was obtained the following knowledge.

1. The largest amount of informal communication was between sitter and migrant by survey analysis.

2. The amount of informal communication of per person per day between sitter and migrant and between migrant and migrant was $0.75 \mathrm{~h}$.

3. The number of occurrences of informal communication was greater in the case of a galleried corridor type as the simulation results.
\end{abstract}

\section{Keywords : Workplace productivity, Human behavior simulation, Multi-agent-system. Informal communication} 知的生産性, 行動シミュレーション, マルチエージェントシステム, インフォーマルコミュニケーション

\section{1. 序}

\section{1 研究の背景}

IT 機器や通信ネットワークの発達により社内での一般的な業務 や情報伝達はパソコン画面上で対応することが通常になっている。 ホームオフィスやサテライトオフィスといった業務形態も業種によ っては進んでいる。そのため物理的なオフィス空間では、フェイス トゥフェイスでのコミュニケーション機能が求められる。具体的に はアイデア出しのブレーンストーミング、方針決定、戦略構築、合 意形成、利害調整、交渉などである。これらの機能を効果的にす寸 めるためには、日常的な素地として、また潤滑油的な役割として、 休数時や空間内移動時のインフォーマルコミュニケーションが重要 な役割を占めることとなる。

インフォーマルコミュニケーションの重要性については、前報 1) で詳述している。国土交通省の知的生産性研究委員会報告書 ${ }^{2)}$ の建 築空間と知的活動の階層モデル」での 7 つ Behavior 注 1) の内の 1つとしてのインフォーマルコミュニケーション（偶発的な雑談や 打合せ）、岡本 3)による偶発的なコミュニケーションを誘発すること
での組織の枠を超えた知識変換促進、緑川ら ${ }^{4)}$ のコュニケーショ ンの満足度が高まることによるスムーズな情報の伝達などである。

筆者らは、インフォーマルコミュニケーションを調査し知見を積 み上げることで、知的生産性向上を目指した執務空間の設計に役立 てることを目的とした研究を行なっている。前報 1)では実際の建物 において組織の移転等による統合前後でコミュニケーション行動に 関して主観的評価と客観的評価の両面についての実態調查を行なっ た。具体的には、執務者へのアンケートによる主観的評価とインタ 一バルカメラによる客観的評価の両方を評価手法として用い、統合 前後でのコミュニケーションの状況を比較した。また分散した執務 空間を統合したことにより、統合や環境の変化がコミュニケーショ ンを含む働き方・働きやすさに与える影響を把握した。本報では、 偶発的出会いによるインフォーマルコミュニケーションの発生量や 場所を設計段階において評価することを目的としてモデリングされ た行動シミュレーションの有効性を検証し、感度解析を行なう。

1.2 行動シミュレーションに関する既往の研究と本研究の目的お よび方法

\footnotetext{
* (制竹中工務店

*** 東京大学生産技術研究所 教授.工博

*** (侏) SUEP. (当時、東京大学大学院修士課程)
}

Takenaka Corporation

Prof., Institute of Industrial Science, The University of Tokyo, Dr.Eng.

SUEP. Co., Ltd./Former Master Course Student, Graduate School of Engineering, The University of Tokyo 
知的生産性の向上を検証する手法としては、上記のアンケートや 撮影による実態調查とは別に、設計段階での建築主とのコミュニケ ーションツールとして、マルチエージェントモデルを用いた行動シ ミュレーションが有効であると考えられる。マルチエージェントシ ミュレーションについては過去に避難時等の群集歩行に関する研究 が多くなされてきた。谷本ら 5)は、避難口のボトルネック効果に関 して検討し、衝突により人のアーチが形成される現実的状況下では 避難口前の空間に障害物を設置することにより人の流れを整流する ことで避難口の流動効率を改善できることを演繹的に示した。藤岡 ら ${ }^{6)}$ は、津波避難の対策として、予想される避難猶予時間に応じて 避難誘導システムを変更する方がより多くの人命安全が期待できる ことを示した。佐野ら 》は、「人間行動シミュレーション及び人間行 動モデル構築の基礎となる行動研究」に関係する研究成果をデジタ ルアーカイブとして集積した。その結果、実際のプロジェクトへの 適用は火災避難分野に関するものが多く、日常時の群集流動シミュ レーションを用いた評価については、実プロジェクトに計画段階か ら取り入れられる例が少ない点を指摘した。また実際の行動をモデ ル化しシミュレーションした事例としては次のような研究がある。 織田ら ${ }^{8)}$ は、現実に近いボトムアップな人間行動シミュレータをめ ざし、連続的空間とエージェントシステムの概念を応用したプリミ ティブな人間行動シミュレータを提案した。具体的な対象空間とし て学生食堂にて試行し、テーブルの配置パターンにより空間の混雑 度が異なること等の知見を得た。加藤ら 9)、10)は、大学キャンパスの 食堂を対象にシミュレーション上で概ね実際の座席選択と同様の傾 向を持つ座席選択パターンを再現した。それをふまえ座席数を減ら したレイアウト変更案を提示した。木曽ら 11) 13) は、大学構内におけ る滞留場所でのビデオカメラによる実測をふまえた行動シミュレー ションをおこなった。広場内における滞留などの人間行動の環境に 対する感度について分析した。秋元ら 14) 17)は、オフィス空間にお ける時間利用者数やエージェント同士の遭遇位置と回数について実 測調查（目視調査とアンケート調查を併用）と比較し、執務者活動 を再現することに成功した。

次にインフォーマルコミュニケーションが発生する場所について 既往研究をみると、前述の緑川 4) らのアンケート調査によれば、知 識創造職務は情報・知識処理職務に比ベ、コミュニケーションを重 要視する傾向がみられ、勤務中に利用する空間も会議室や共有空間、 外構空間の利用の利用割合が高かった。また割田 18) らは、インフ オーマルコミュニケーションに高い影響を与える建築空間として、 打合せスペース、ライブラリー、リフレッシュスペースがあること を執務者アンケートにより見出した。宗方 19）らは、情報交換の場 として、休款空間（食堂、休款室、給湯室等）、移動空間（階段、 廊下、エントランス等）といった本来生産の場として想定されてい ない空間が知的生産性に寄与していることをアンケートにより確認 した。金子 20) は、レーザーセンサーを利用した行動モニタリング 手法により、コピー機、庶務席周辺等の交流量が多い場所で偶発的 な立ち話が多いことを確認した。流田 $\left.{ }^{21}\right)$ らは、目視調查により、 ミーティングスペースだけでなく、自席や通路、マグネットスペー ス（什器や給湯がある場所）等でコミュニケーションが多く発生し ていることを確認した。藤田 22) らは、オフィス内での観察調査に よりワーカーの交流分析を行ない、会話の起こりやすい場所は喫煙
スペース、OA コーナー等の共用スペースであり、移動の途中での 偶発的な発生が多いことを確認した。特に会話発生状況として部門 間の会話は経路の途中で偶発的に起こる会話が最も多かった。さら に座席位置と共用スペース等の頻繁に使うゾーンの距離が長くなれ ば偶発的会話が増える点を示唆した。

以上の既往の研究をふまえると、オフィスを構成する建築空間の 要素やそのレイアウトがインフォーマルコミュニケーションに影響 していることが示唆されたが、知的生産性向上の観点から、オフィ スレイアウトを決定するために効果的な要素となるものを見出すこ とに取り組んでいるものが少ない。マルチエージェントモデルを用 いてオフィスにおける知的生産性向上を検討する方法の一つとして、 インフォーマルコミュニケーションに関する感度解析が不足してい るものと考えられる。そこで本研究では、知的生産性向上（インフ オーマルコミュニケーション量の向上）を評価指標とした場合の建 築主との合意形成ツールとしての実用化を目指したマルチエージェ ントシステムを用いた行動シミュレーション23)を使い、執務室の標 準モデルにおいて、コピー機や机のレイアウトの違いなどに関する 感度解析を行なった。前述のようにインフォーマルコミュニケーシ ヨンは様々な場所で行われるが、今回はオフィスにおいてコピー機 や会議室の位置、机のレイアウト等による動線の制約がもたらすイ ンフォーマルコミュニケーションの違いに焦点をしぼり検討した。 シミュレーションのためのエージェントの業務内容 (タスクと称す) には、前報 1)の執務者へのアンケートに基づく実態調査の分析結果 を用いた。またシミュレーションでは着席者同士のインフォーマル コミュニケーション量が算出されないため、前報のインターバルカ メラ調查結果について着席者や離席者のコミュニケーションのバリ エーションを分析した。

本研究の目的は 2 つる。一つ目は執務空間のインフォーマルコ ミュニケーションに関する前報の実態調查を分析して行動シミュレ ーションモデルに応用し、そのシミュレーションの有効性を検証す ることである。二つ目はその行動シミュレーションを標準モデルの オフィスに用いて感度解析を行なうことにより、知的生産性向上の 検討に寄与する知見を得ることである。

\section{2. 解析手法}

本研究では、執務空間を対象としたワーカーの行動をシミュレー トする解析ツールとして、 $\operatorname{artisoc}^{24)}$ 注 1) をべースにして構築したシ ミュレーションツールを使用した。以下、本研究において入力条件 となる空間モデルと人間のモデルおよびタスク等について述べる。

\section{1 空間モデル}

空閒は二次元平面上に表現される。空閒表現の基本要素は、エー ジェントが移動可能なオブジェクト（床）と、移動不可能なオブジ エクト（壁）、移動できないが視線は通るためにインフォーマルコ ミュニケーションが生じるオブジェクト（家具）の３つから成る。

\section{2 人間モデル}

（1）エージェントの歩行速度は $1.3 \mathrm{~m} / \mathrm{s}$ とし、目的地までの最短経 路を選択する。

（2）エージェントの出社時刻と退社時刻は定時を中心とした正規 分布とした。

（3）在席人数は、人数（デー夕個数）と外出率から計算される。 


\section{3 エージェントのタスク}

一日のスケジュールはタスクに割り付けられる。タスクには個別 タスクと会議タスクがある。会議タスクのみ、複数のエージェント が同時に行なう必要があるため、個別タスクと会議タスクは別々の アルゴリズムで成り立っている。

一日のスケジュールを設定する際には、まず「会議タスク」を複 数のエージェントについて調整して事前に設定する。

次に個別タスクを設定する。会議時間を出社時刻から退社時刻の 間で割り付けた残りの時間のなかで割り付けることとなる。具体的 な個別タスクとしては、デスクワーク、コピー、休憩（執務室外）、 電話対応、トイレ、外出がある。タスクは内容と発生確率と継続時 間の 3 つ要素で構成される。これらのタスクは確率分布に従う乱 数によって設定し、タスク終了時には次のタスクが会議タスクでな い場合には、あらためて乱数によりタスクが設定される。あるタス クの開始時間となった時、エージェントはタスク実行エリアまで移 動し、そこで定められている継続時間分を過ごす。またデスクワー クタスクは、スケジュールを生成する際に全員に自席が割り当てら れ、そこで実行される。しかしコピータスク等の自席とは別の場所 で実行されるタスクで、タスク実行エリアが他のエージェントに占 められている場合は、そのタスクはキャンセルされて自席に戻るこ ととなる。タスクの実行時間は継続時間の $0.5 \sim 1.5$ 倍の範囲で調整 されるものとしている。なおこのタスクの発生確率と継続時間は後 述の実態調查の分析により設定值を決定している。

\section{4 コミュニケーションの扱いについて}

コミュニケーションには、フォーマルコミュニケーションとイン フォーマルコミュニケーションの 2 種類がある注2)。フォーマルコミ ユニケーションは予定されている会議であり、インフォーマルコミ ユニケーションは偶発的に発生するものである。フォーマルコミュ ニケーションは前述の会議タスクでありエージェントの一日のスケ ジュールの中に事前に設定しておく。インフォーマルコミュニケー ションはそれぞれのタスクを実行するために移動しているエージェ ントに発生するものとする。インフォーマルコミュニケーションは 1 対 1 で行われるものとし、どちらかのエージェントが移動してい るときに発生する。エドワード・ホール 25) の社会距離注3) を参考に、

2 人のエージェントの距離が $3.0 \mathrm{~m}$ 以内になった場合に設定した発 生確率 $3 \%$ に基づいて話しかけるものとし、話しかけられたエージ エントは $100 \%$ 応対することとする。すなわち、インフォーマルコ ミュニケーション発生確率については、実測結果も勘案し、本研究 では $3 \%$ と仮定する。移動中のエージェントが話しかけるのは、同 じく移動中のエージェントもしくはデスクワークタスクを実行して いるエージェントである。複数のエージェントがコミュニケーショ ンを行なう場合には、2エージェント間のコミュニケーションが複 数あるものとする。インフォーマルコミュニケーションの継続時間 は五十嵐らの研究 ${ }^{26)}$ を参考に継続時間とその確率を算出し、図 1 に示すステップ関数として取り扱う。

インフォーマルコミュニケーション発生確率の設定条件は、イン フォーマルコミュニケーション量の絶対量に大きく影響する。図 4 にて後述するが、コミュニケーション発生確率の違いによるコミュ ニケーション量をみると、1\%〜 5\%の間では線形に変化するといえ る。本シミュレーションは前述の通りインフォーマルコミュニケー
ション量の向上を評価指標とした建築主との合意形成ツールである。 具体的には複数のレイアウト案に対するインフォーマルコミュニケ ーション量を相対的に比較するツールとしての利用が見込まれるた め、この線形に変化する範囲内では、どの発生確率を用いてもレイ アウト案同士の相対的なコミュニケーションの関係を把握するには 決定的な計算条件ではないものと考えられる。

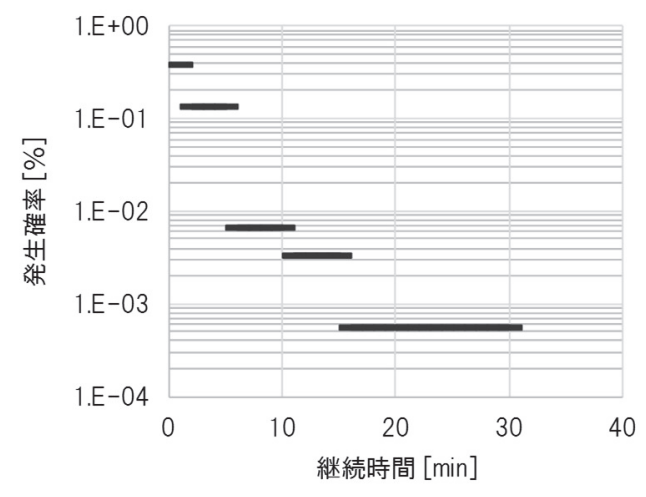

図 1 インフォーマルコミュニケーションの継続時間

\section{5 シミュレーションアウトプットとしてのインフォーマルコミ} ユニケーション

上記の設定により発生したインフォーマルコミュニケーションの ログをシミュレーションのアウトプットとする。具体的なログは、

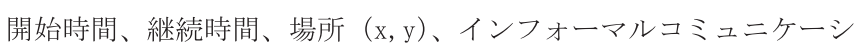
ヨンを行なったエージェントの ID（2 名）である。

\section{3. シミュレーションにおける条件設定のためのタスクに関する実 態調査結果の分析 \\ 3.1 執務者へのアンケート調査概要}

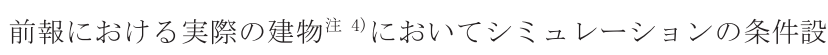
定のための調查をおこなった。給湯器メーカーの研究開発施設であ る。デスクスペースはワンフロアであり、床面積は $1 、 372.99 \mathrm{~m}^{2}$ で ある。執務者は 140 名である。調查は 2013 年夏のコミュニケーシ ヨンに関するアンケート調査の際に行なった。タスクに関する 1 回 の継続時間と発生確率について調查した。調查方法はアンケート用 紙に以下の点を記載してもらう形とした。アンケート対象期間は 2 週間とした。

(1)勤務時間内において外出している時間の割合（\%)

(2)外出のない一日の勤務時間（時間）

(3)外出のない一日の業務の 1 回あたりの継続時間(分) と回数 (回)

(4)業務の種類は以下とした。

a)執務室での打合せ

b)休憩（自席で行なう休憩は除く）

c)トイレ

d)コピー・プリンタの利用

e)電話応対時の離席

f)執務室以外（5 ケ所）での作業や打合せ

\section{2 調査結果に基づく入力条件の決定}

\subsection{1 タスクの 1 回の継続時間}

表 1 にタスクの 1 回の継続時間の入力条件（min）について示す。 
あわせて各課の人数と外出率も記載する。デスクワークは回答しに くいものと考え、60 分と仮定した。

表 1 タスクの 1 回の継続時間の入力条件 (min)

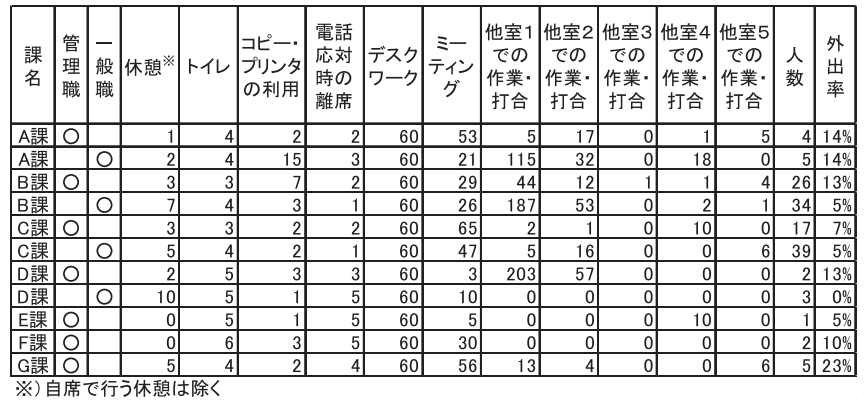

\subsection{2 タスクの発生確率}

表 2 にタスクの発生確率の入力条件について示す。外出のない一 日の業務の回数から比率を求めた。

\section{表 2 タスクの発生確率の入力条件}

\begin{tabular}{|c|c|c|c|c|c|c|c|c|c|c|c|c|c|}
\hline $\begin{array}{l}\text { 課 } \\
\text { 名 }\end{array}$ & \begin{tabular}{|l|} 
管 \\
職 \\
僮
\end{tabular} & $\begin{array}{l}- \\
\text { 般 } \\
\text { 職 }\end{array}$ & 休䕀＊ & トイレ & \begin{tabular}{|l} 
コピーー \\
プリンタ \\
の利用
\end{tabular} & $\begin{array}{l}\text { 電話 } \\
\text { 億対 } \\
\text { 時の席 } \\
\text { 離保 }\end{array}$ & \begin{tabular}{|l} 
デスク \\
ワー
\end{tabular} & $\begin{array}{l}\text { ミ- } \\
\text { テイ } \\
\text { グ }\end{array}$ & $\begin{array}{l}\text { 他室1 } \\
\text { での } \\
\text { 作業. } \\
\text { 打合 }\end{array}$ & \begin{tabular}{|c|} 
他室2 \\
での \\
作業. \\
打合
\end{tabular} & $\mid$\begin{tabular}{c|c} 
他室3 \\
での \\
作業. \\
打合
\end{tabular} & $\begin{array}{l}\text { 他室4 } \\
\text { での } \\
\text { 作業. } \\
\text { 打合 }\end{array}$ & $\mid \begin{array}{c}\text { 他室5 } \\
\text { での } \\
\text { 作業. } \\
\text { 打合 }\end{array}$ \\
\hline A課 & 0 & & $0.0 \%$ & $11.5 \%$ & $26.9 \%$ & $11.5 \%$ & $30.8 \%$ & $11.5 \%$ & $1.7 \%$ & $6.0 \%$ & $0.0 \%$ & $0.0 \%$ & $0.0 \%$ \\
\hline A課 & & 0 & $0.0 \%$ & $12.5 \%$ & $18.8 \%$ & $6.3 \%$ & $31.3 \%$ & $12.5 \%$ & $14.6 \%$ & $4.1 \%$ & $0.0 \%$ & $0.0 \%$ & $0.0 \%$ \\
\hline B課 & 0 & & $4.5 \%$ & $18.2 \%$ & $22.7 \%$ & $4.5 \%$ & $27.3 \%$ & $13.6 \%$ & $7.1 \%$ & $2.0 \%$ & $0.0 \%$ & $0.0 \%$ & $0.0 \%$ \\
\hline B課 & & 0 & $7.1 \%$ & $21.4 \%$ & $21.4 \%$ & $7.1 \%$ & $21.4 \%$ & $7.1 \%$ & $11.1 \%$ & $3.1 \%$ & $0.0 \%$ & $0.0 \%$ & $0.0 \%$ \\
\hline C課 & 4 & & $0.0 \%$ & $17.6 \%$ & $23.5 \%$ & $5.9 \%$ & $41.2 \%$ & $11.8 \%$ & $0.0 \%$ & $0.0 \%$ & $0.0 \%$ & $0.0 \%$ & $0.0 \%$ \\
\hline C課 & & 0 & $5.3 \%$ & $21.0 \%$ & $21.0 \%$ & $11.0 \%$ & $36.8 \%$ & $5.3 \%$ & $0.0 \%$ & $0.0 \%$ & $0.0 \%$ & $0.0 \%$ & $0.0 \%$ \\
\hline D課 & 0 & & $5.6 \%$ & $27.8 \%$ & $11.1 \%$ & $11.1 \%$ & $22.2 \%$ & $16.7 \%$ & $4.3 \%$ & $1.2 \%$ & $0.0 \%$ & $0.0 \%$ & \\
\hline D課 & & 0 & $5.6 \%$ & $27.8 \%$ & $5.6 \%$ & $16.7 \%$ & $38.9 \%$ & $5.6 \%$ & $0.0 \%$ & $0.0 \%$ & $0.0 \%$ & $0.0 \%$ & 0.0 \\
\hline 課 & $\underline{0}$ & & $0.0 \%$ & $17.4 \%$ & $21.7 \%$ & $4.3 \%$ & \begin{tabular}{|l|l}
$39.1 \%$ \\
\end{tabular} & $8.7 \%$ & $0.0 \%$ & $0.0 \%$ & $0.0 \%$ & $8.7 \%$ & $0.0 \%$ \\
\hline 課 & 0 & & $0.0 \%$ & $25.0 \%$ & $25.0 \%$ & $5.0 \%$ & $30.0 \%$ & $15.0 \%$ & $0.0 \%$ & $0.0 \%$ & $0.0 \%$ & $0.0 \%$ & $0.0 \%$ \\
\hline & 은 & & 0.0 & $14.3 \%$ & 23. & $11.3 \%$ & \begin{tabular}{|l|l|}
$28.6 \%$ \\
\end{tabular} & $9.5 \%$ & $3.7 \%$ & $1.0 \%$ & $0.0 \%$ & $0.0 \%$ & 4.8 \\
\hline
\end{tabular}

4. 着席および離席の状況によるインフォーマルコミュニケーショ ンの実態調査結果の分析（行動シミュレーションで対象となるコミ ユニケーション量の分析)

\section{1 調査概要}

前述のように研究対象である行動シミュレーションでは着席者と 離席者もしくは離席者同士（歩行者同士）のインフォーマルコミュ ニケーションを対象としており、着席者同士のインフォーマルコミ ユニケーションは対象外である。そのため前報でのインフォーマル コミュニケーション調査結果を分析し、着席および離席の状況によ り分類した。2013/7/22(月) 26 (金)の 5 日間についての調査である。

\section{2 調査結果}

図 2 に分類結果を示す。

口着席者同士 口着席者十離席者 口歩行者同士

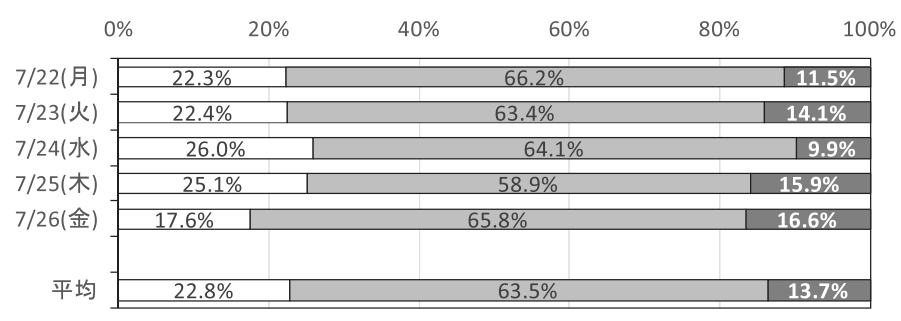

図 2 インフォーマルコミュニケーション量の

着席・離席状況による分類
5 日間の平均值を見ると、インフォーマルコミュニケーションの 中での割合は、着席者同士が $22.8 \%$ 、着席者十離席者が $63.5 \%$ 、歩行 者同士が $13.7 \%$ ありり、着席者と離席者によるインフォーマルコミ ユニケーションが一番多かった。行動シミュレーションの解析対象 となる着席者十離席者、および歩行者同士によるインフォーマルコ

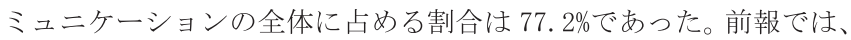
個人席周辺のコミュニケーション量が $0.98 \mathrm{~h} /$ 人日であったことか ら、着席者十離席者、および歩行者同士によるコミュニケーション 量は、0.76h/人日である。

\section{5. 実態調査分析結果の行動シミュレーションへの応用 5.1 計算条件}

実態調查を行なった建物において行動シミュレーションを実施し た。計算対象建物は、三角形の平面形態を有効に活用す心゙く中庭を 内包するプランとし、中庭に面したデスク脇のオープンスペースを 通路として活用することでインフォーマルコミュニケーションが増 えることをねらいとしたものである。人が並んで歩くことができる ため物理的な対人距離を縮めることができ、着席した人と通路歩行 者が出会う頻度も増加する。今回は、レイアウト変更案についても あわせて計算した。眓 3 に計算をおこなったレイアウトを示す。次

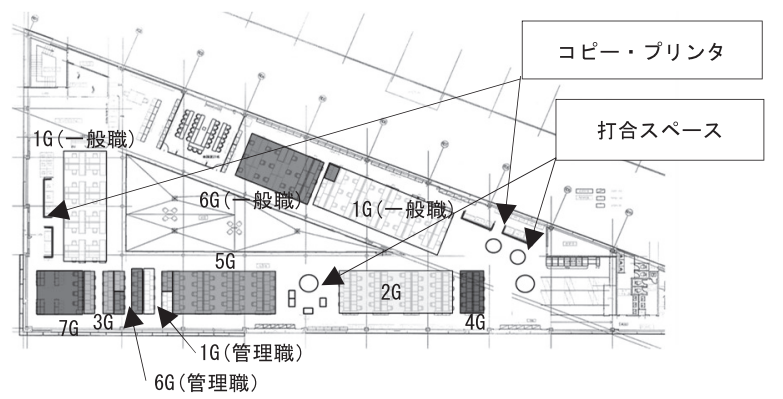

（a）実際の建物でのレイアウト

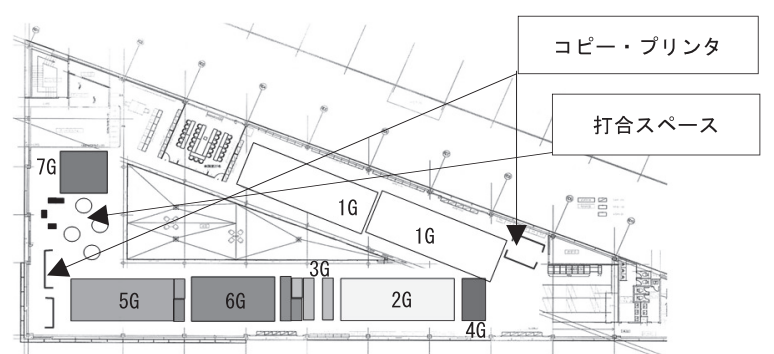

(b) レイアウト変更案 1

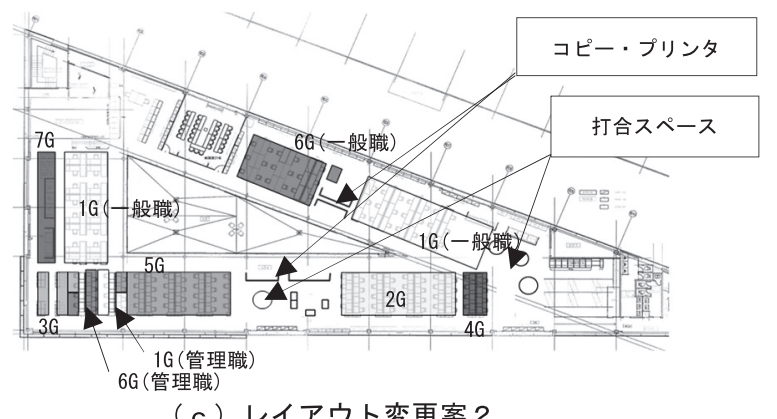

図 3 実際の建物でのレイアウトの検討プラン 
の3つのレイアウトの違いによるインフォーマルコミュニケーショ ン量の比較を行なった。まず実際の建物でのレイアウト (図 $3(\mathrm{a})$ ) はコピー機を分散設置し、一部の部署の管理職と一般職を分離した ものである。それに対し、レイアウト変更案 1 (図 3（b ））は打合 スペースを集約し、かつ部署内コミュニケーション頻度の向上をね らったもの、レイアウト変更案 2 (図 $3(\mathrm{c})$ ) はコピー機を北側と 南側の島の中央に集めてコピー機利用者と歩行者のインフォーマル コミュニケーションの誘発をねらったものである。なお前述の表 1 および 2 の $\mathrm{A}$ 課から $\mathrm{G}$ 課がグループに分かれて編成されている。

\section{2 計算結果および考察}

図 4 にコミュニケーション発生確率の違いによるコミュニケーシ ヨン量の比較を示す。図 3（a）の実際の建物でのレイアウトにお いて、発生確率を $1 \% 、 3 \% 、 5 \%$ で比較した。インフォーマルコミ ユニケーション量（h/人日）は、 $1 \%$ で $0.18 、 3 \%$ で $0.55 、 5 \%$ で 0.92 であった。本シミュレーションにおいては、コミュニケーショ ン発生確率を変更することによって、インフォーマルコミュニケー ション量は線形に変化するものといえる。前述の実態調査（図 2) によるインフォーマルコミュニケーション量が 0.76 であったこと から、3\%で計算した時の 0.55 とは大きな誤差はなく、インフォー マルコミュニケーション発生確率を $1 \%$ \% $5 \%$ の間に設定すること の妥当性を確認できた。

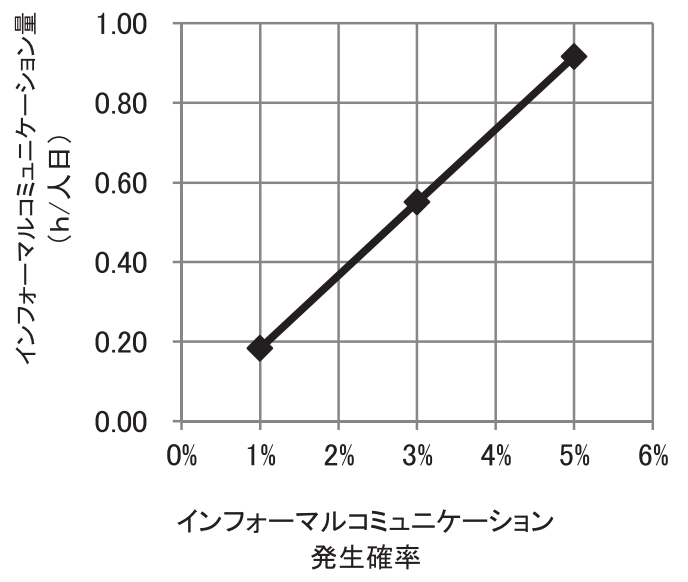

図 4 コミュニケーションの発生確率の違いによる コミュニケーション量の比較（図３（a）の場合）

次に上記のレイアウトの違いによるインフォーマルコミュニケー ションの計算結果としての一人あたりの一日のコミュニケーション 量（h/人日）を図 5 に示す。実際の建物レイアウトでは 0.55 、レイ アウト変更案 1 では 0.52 、レイアウト変更案 2 も 0.52 であった。

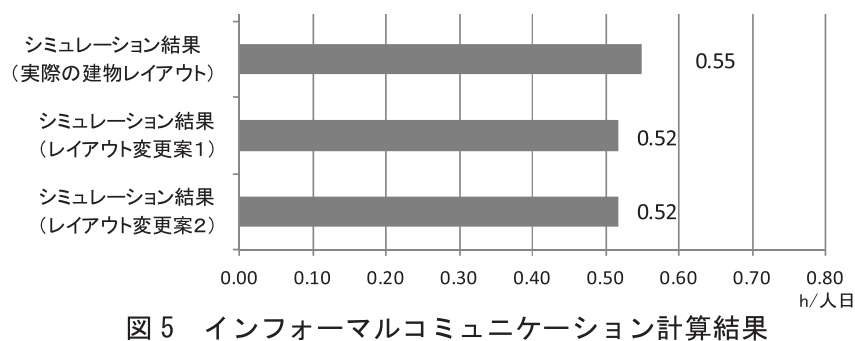

これら 3 つのイアウトの違いでは、インフォーマルコミュニケ
ーション回数には大きな差が見られなかった。その原因として回廊 型のオフィスであることがインフォーマルコミュニケーションの回 数を増やすことに大きく貢献している可能性が考えられる。そのた め後述の標準モデルプランにおける感度解析では回廊型の感度も検 討対象とする。

\section{6. 標準モデルプランにおける感度解析}

\section{1 計算モデル}

文献 1 の建物のプランでは特殊性がある可能性をふまえ、標準モ デルプランに設定した執務室は基準階オフィスビル注5)とした。

建築設計資料集成 30)のデスクレイアウトを参考に机サイズと通 路幅を設定した。具体的には、机のサイズを 1 台あたり幅 $1,200 \mathrm{~mm}$ $\times$ 奥行 $900 \mathrm{~mm}$ 、通路幅を $1,200 \mathrm{~mm}$ 以上とした。机以外の家具什器 類として、コピー機を 2 台、4 種類の書架 (幅 $2,700 \mathrm{~mm} 、 3,000 \mathrm{~mm}$ 、 $3,600 \mathrm{~mm} 、 4,200 \mathrm{~mm}$ 、奥行はいずれも $600 \mathrm{~mm}$ ）を机のレイアウト 状況に応じて設置した。またフォーマルコミュニケーションを行な うための会議室に該当するものとしての打合スペースについては 4 席 1 組 ( 1 テーブルが幅 $1,200 \mathrm{~mm} \times$ 奥行 $900 \mathrm{~mm}$ を 4 つ組み合わせ たもの）を 2 ヶ所とした。これらにより在席人数は 56 人、在席人 数の原単位は 0.14 人 $/ \mathrm{m}^{2}$ となった。

\section{2 タスクの設定}

前述の実態調查を参考にしてタスクを設定した。設定内容は表 3 に示す。実態調査と異なる点として、以下の 4 点がある。

(1)電話応対のタスクが自席タスクとなった。

(2)執務室以外（5 ケ所）での作業や打合せの内、アンケート結果で の発生確率が概ねゼロであった他室は除いた。

(3) $1 \mathrm{~F}$ での作業・打合せのタスクについては、標準モデルではフロ アの区別がないため外出タスクに変更した。

(4)出社時刻は 8 時 30 分、退社時刻は 20 時とし、いずれもそれら を中心とした正規分布とした。

表 3 タスクの発生確率と継続時間

\begin{tabular}{|c|c|c|c|c|c|c|c|c|}
\hline 夕名称 & $\begin{array}{l}\text { デスク } \\
\text { ワーク }\end{array}$ & 会議 & コピー & 休㮩 & $\begin{array}{l}\text { 電話 } \\
\text { 応対 }\end{array}$ & WC & 他1 & 他2 \\
\hline \begin{tabular}{l|l} 
ク & $\begin{array}{l}\text { 発生 } \\
\text { 場所 }\end{array}$
\end{tabular} & 自席 & 会議室 & $\begin{array}{c}\text { コピー } \\
\text { 機 }\end{array}$ & $\begin{array}{c}\text { 執務室 } \\
\text { 外 }\end{array}$ & 自席 & トイレ & \begin{tabular}{|} 
執務室 \\
外
\end{tabular} & \begin{tabular}{|c} 
執務室 \\
外
\end{tabular} \\
\hline $\begin{array}{l}\text { 発生 } \\
\text { (\%) }\end{array}$ & 31 & 9 & 22 & 4 & 8 & 20 & 5 & 1 \\
\hline $\begin{array}{l}\text { 継続 } \\
\text { 時間 } \\
\text { (min) }\end{array}$ & 60.00 & 38.51 & 3.42 & 4.57 & 2.00 & 3.97 & \begin{tabular}{|l|l}
63.57 \\
\end{tabular} & 22.62 \\
\hline
\end{tabular}

\section{3 解析ケース}

藤田 22 ) らの既往の研究もふまえて、オフィス内での移動距離が 長くなることで、偶発的出会いが増えるものと想定し、その影響が 出ると考えられる要素を感度解析の対象とした。具体的には、コピ 一機の位置（分散と集約）、机の島の雁行の有無、机の向き（南北 軸と東西軸)、会議室の位置 (集約と分散)、パーティションの有無、 通路の場所である。執務環境内での執務者の歩行が生じることとな るコピー機や会議室の位置を変化させることで、移動経路を変化さ せた。また移動距離を変えるために机のレイアウトを雁行や向きに 
よって変化させた。さらにパーティションによって通路の位置を変 化させた。これらにより図 6 に示す 24 ケースでの比較をおこなっ た。コピー機は 2 台を南北に分散した場合と室中央に集約した場合 を比較した。雁行については机の島の組み合わせを変更し通路を雁 行させた。机の向きは 8 人で 1 島を形成することを基本として、そ の島の向きを南北軸とするか東西軸にするかについて比較した。会 議室の位置は集約と分散での比較を行った。パーティション（間仕 切壁）は視線だけでなく動線をふさぐものとし、有無の比較と有り の場合には設置場所によって主動線を変更した。外側に立てて主動 線を室中央に集めたものと、内側に立てて主導線を室外周部（回廊
型）にしたものである。なおサンプル数は杉崎ら ${ }^{311}$ の研究により 15 回とした。

\section{4 計算結果および考察}

6.4.1 各ケースにおけるインフォーマルコミュニケーションの発 生回数の比較

図 7 に各ケースにおけるインフォーマルコミュニケーションの発 生回数を示す。発生回数の多かった上位 3 ケースは、case23（コピ 一機 : 分散、雁行なし、机の向き: 東西、会議室 : 集約、パーティ ションあり (回廊型)）(平均值 257num./day)、case20（コピー機： 集約、雁行なし、机の向き: 南北、会議室 : 集約、パーティション

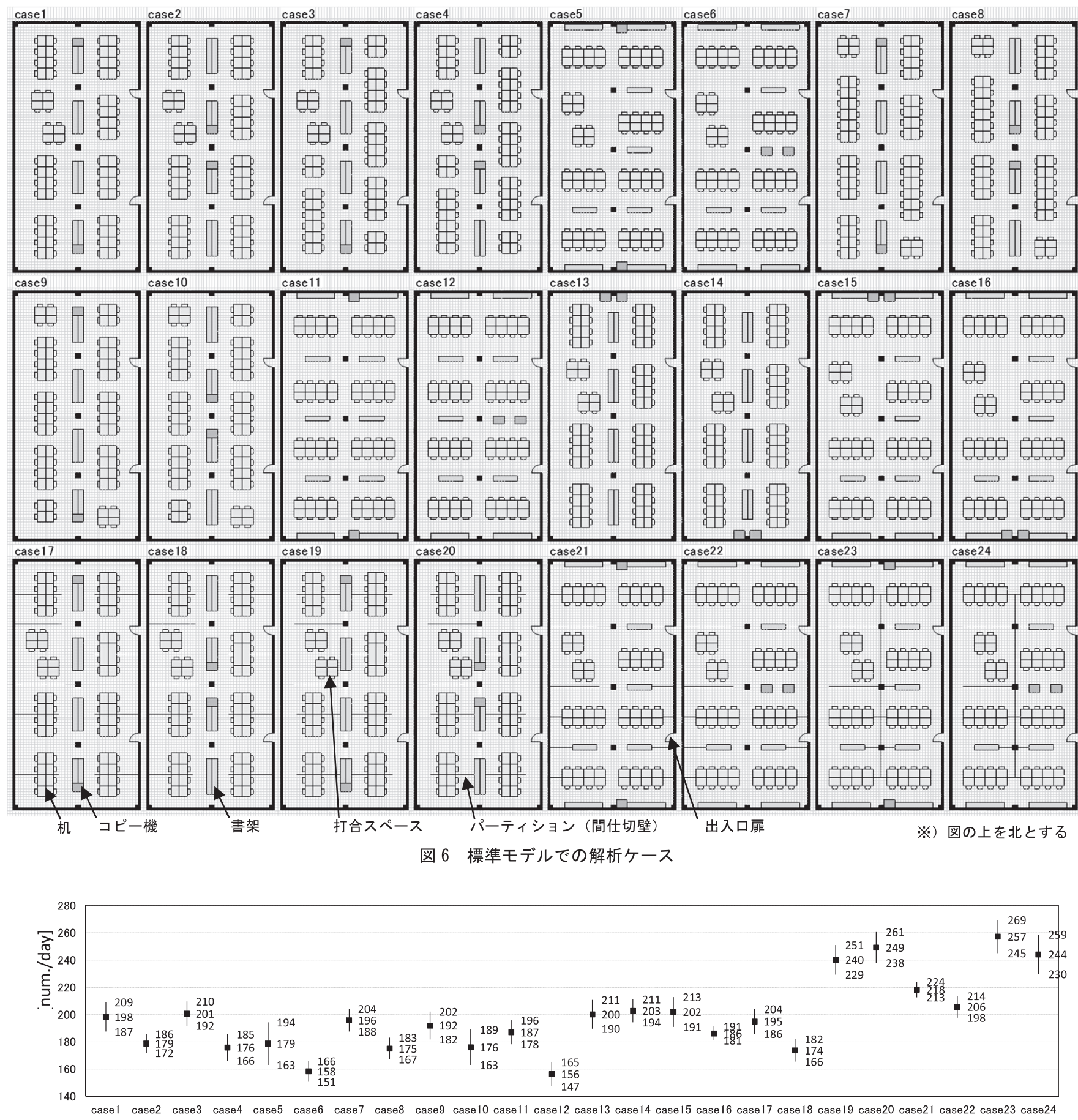

図 7 各ケースにおけるインフォーマルコミュニケーションの発生回数 
あり(回廊型)）(平均值 249num./day)、case24（コピー機 : 集約、 雁行なし、机の向き: 東西、会議室: 集約、パーティションあり(回 廊型）（平均值 $244 \mathrm{num} . / \mathrm{day}$ ）であった。いずれもパーティション あり (回廊型) であった。一方発生回数の少なかった 3 ケースは、 case12 (コピー機 : 集約、雁行なし、机の向き: 東西、会議室 : 分 散、パーティションなし)（平均值 156num./day)、case6（コピー 機: 集約、雁行なし、机の向き: 東西、会議室 : 集約、パーティシ ヨンなし) (平均值 158num./day)、case18（コピー機：集約、雁行 なし、机の向き：南北、会議室 : 集約、パーティションあり（主動 線室中央)）(平均值 $174 \mathrm{num} . /$ day）であった。いずれもコピー機を 集約した場合であった。

以下に各変数についての結果と考察を記す。それぞれの変数内の バリエーションでの比較を行なった。その際、各ケースの平均值の 差について $\mathrm{t}$ 検定（有意水準 $5 \%$ 以下）を行なった。

\subsection{2 コピー機の位置（分散と集約）(表 4)}

コピー機の位置は、中央に集約するよりも、南北に分散させるほ うが、インフォーマルコミュニケーション発生回数が多く有意な差 がみられた。

コピー機を分散することによりエージェントの移動量が増加した ものと考えられる。この点は藤田 ${ }^{22}$ ) らが示唆した、座席位置と共 用スペース等の頻繁に使うゾーンの距離が長くなれば偶発的会話が 増える点について、今回検討した動線の範囲では整合する結果とな ったものと考えられる。

\subsection{3 机の島の雁行の有無 (表 5 )}

雁行の有無は、ケースによってインフォーマルコミュニケーショ ン発生回数の増減の両方があった。有意差はみられなかった。

このプランでの雁行は変化を生むほどの大きな差とはいえないも のと考えられる。

\section{4.4 机の向き（南北軸と東西軸）（表 6 ）}

有意な差があるものだけについてみると、パーティションがない 場合には南北軸、パーティションがある場合には、東西軸であった。

$1 \mathrm{vs} 5$ と 17vs21 を比較すると、プラン上は家具什器類のレイアウ 卜は同じであるがパーティションの有無だけが異なる。すなわち 1vs5 ではパーティションがないが、17vs21 ではパーティションが 存在する。ここでエージェントの動線と在席者の背面の関係をみる と、1vs5 では背面を通過する距離を長く確保できる case1 の方が多 くなる。パーティションがない場合には最短距離を歩くことになる ため、長手方向に沿って机が並ぶため移動者が在席者と出会う機会 が増えるものと考えられる。一方パーティションのある 17vs21 で は 21 の方が背面を通過する距離が長くなり、インフォーマルコミ ユニケーション回数も増加している。これはパーティションがある ことにより動線が限定され、2 箇所の出入り口までの動線で出会う 在席者は東西軸で増えることが影響している。

\subsection{5 会議室の位置（集約と分散）（表 7 ）}

会議室（打合スペース）の配置は、ケースによってインフォーマ ルコミュニケーション発生回数の増減の両方があったが、集約のほ うが多い傾向にあった。有意差はみられなかった。

\section{4.6 パーティションの有無（表 8 ）}

有意差がみられたのはパーティションがある方が大きかった場合 のみであった。
前述の図 6 のすべてのケースの比較における上位 3 ケースのいず れもがパーティションあり（回廊型）であったことと同様にパーテ イションの影響度が高いものと考えられる。

\section{4.7 主動線（通路の場所）（表 9）}

いずれも回廊型の方が多く、かつ有意な差がみられた。

主動線については室中央にまとめるよりも回廊型にする方が出入 り口までの距離が長くなり、その分で偶発的な出会いを増やすこと となるものと考えられる。回廊型とすることがインフォーマルコミ ユニケーション回数を増加させる重要な感度となると考えると、実 態調査のプランにおけるレイアウト変更の検討のシミュレーション においては感度の高い回廊型の中だけでの比較をしていたというこ とであり、他の要素の変化が感度として現れにくかったものと考え られる。

\section{7. まとめ}

本研究の目的は執務空間のインフォーマルコミュニケーションに 関する実態調查の分析結果を行動シミュレーションモデルに応用し、 さらに行動シミュレーションを用いて知的生産性向上の検討に寄与. する知見を得ることである。本報では以下の知見を得た。

（1）インフォーマルコミュニケーションの割合は、実態調査では着 席者同士が $22.8 \%$ 、着席者と離席者が $63.5 \%$ 、歩行者同士が $13.7 \%$ あ゙あり、着席者と離席者によるインフォーマルコミュニ ケーションが一番多かった。

（2）実態調査から、着席者十離席者、および歩行者同士によるコミ ユニケーション量は、 $0.76 \mathrm{~h} /$ 人日であった。

（3）インフォーマルコミュニケーションの発生回数の多かった上位 3ケースはいずれもパーティションあり（回廊型）であった。

（4）一方、インフォーマルコミュニケーションの発生回数の少なか った 3 ケースはいずれもコピー機を集約した場合であった。

（5）コピー機の位置は、中央に集約するよりも、南北に分散させる ほうが、インフォーマルコミュニケーション発生回数が多く有 意な差がみられた。

（6）エージェントの移動量（歩行距離）が増加することが、インフ オーマルコミュニケーション量の増加に貢献する点が示唆され た。

\section{謝辞}

本研究の計画と実測調査に関し、研究対象建物の建築主であるパ 一パス怢の方々の全面的なご協力をいただいたことに心から厚く感 謝申し上げます。

注

注 1）artisoc はマルチェージェント・シミュレーション（MAS）における実 行順序制御機構をベースとしグラフィカルユーザインタフェース (GUI) を含めた MAS モデル構築の支援機能を持つ MAS エンジンのオープンソー スである。MAS とは自律的に振る舞うエージェントを定義しあるシステ ム内における多数のエージェントの振る舞いをシミュレートすることで システム全体の振る舞いを観察・解析するボトムアップ的なアプローチ である。MAS ではェージェントの個性を属性として定義するとともに周 囲のエージェントとの相互作用や環境・状況に応じて行動を変化させる 法則を行動ルールとして定義する。この属性や行動ルールを分析対象に 応じて設定することにより、個人内でも様々な要因に応じて行動が変わ る多様性や多くの人や物が場合によっては局所的に影響を及ぼしあう相 
表 4 コピー機の位置（分散と集約）の感度解析結果

\begin{tabular}{|c|c|c|c|c|c|c|c|c|c|}
\hline $\begin{array}{l}\text { case } \\
\text { 比較 }\end{array}$ & コピー & 雁行 & 机向き & 会議室 & パーティション & 主動線 & \multicolumn{2}{|c|}{ 有意差 } & $\begin{array}{l}\text { インフォーマルコミュニケー } \\
\text { ション回数が多かった方 }\end{array}$ \\
\hline 1 vs2 & $\begin{array}{l}\text { 分散 VS 集約 (中) } \\
\end{array}$ & なし & 南北 & 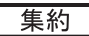 & なし & - & 有 & $p=0.003$ & 分散 \\
\hline $3 \mathrm{vs} 4$ & 分散 VS 集約 (中) & あり & 南北 & 集約 & なし & - & 有 & $p<0.001$ & 分散 \\
\hline $5 \mathrm{vs} 6$ & 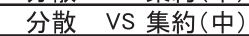 & - & 東西 & 集約 & なし & - & 有 & $p=0.020$ & 分散 \\
\hline $7 \mathrm{vs} 8$ & 分散 VS 集約 (中) & あり & 南北 & 分散 & なし & $\overline{-}$ & 有 & $p=0.001$ & 分散 \\
\hline $9 \mathrm{vs} 10$ & 分散 VS 集約 (中) & あり & 南北 & 分散 & なし & $\begin{array}{l}- \\
\end{array}$ & 有 & $p=0.047$ & 分散 \\
\hline $11 \mathrm{vs} 12$ & $\begin{array}{ll}\text { 分散 VS 集約 (中) } \\
\end{array}$ & - & 東西 & 分散 & なし & - & 有 & $p<0.001$ & 分散 \\
\hline $13 \mathrm{vs} 14$ & 集約(北) VS 集約(南) & なし & 南北 & 集約 & なし & - & & - & 集約(南) \\
\hline $15 \mathrm{vs} 16$ & $\begin{array}{l}\text { 集約(北) VS 集約(南) } \\
\end{array}$ & - & 東西 & 集約 & なし & $\begin{array}{ll}- \\
\end{array}$ & 有 & $p=0.011$ & 集約(北) \\
\hline $17 \mathrm{vs} 18$ & 分散 VS 集約 (中) & なし & 南北 & 集約 & あり & 室中央 & 有 & $p=0.001$ & 分散 \\
\hline 19 vs 20 & 分散 VS 集約 (中) & なし & 南北 & 集約 & あり & 回廊型 & & - & 集約 (中) \\
\hline 21 vs22 & 分散 VS 集約 (中) & - & 東西 & 集約 & あり & 室中央 & & $p=0.010$ & 分散 \\
\hline $23 v s 24$ & 分散 VS 集約 (中) & - & 東西 & 集約 & あり & 回廊型 & & - & 分散 \\
\hline
\end{tabular}

表 5 机の島の雁行の有無の感度解析結果

\begin{tabular}{|c|c|c|c|c|c|c|c|c|}
\hline $\begin{array}{l}\text { case } \\
\text { 比較 }\end{array}$ & コピー & 雁行 & 机向き & 会議室 & パーティション & 主動線 & 有意差 & $\begin{array}{l}\text { インフォーマルコミュニケー } \\
\text { ション回数が多かった方 }\end{array}$ \\
\hline $1 \mathrm{vs} 3$ & 分散 & なし VS あり & 南北 & 集約 & なし & - & - & あり \\
\hline $2 \mathrm{vs} 4$ & 集約(中) & なし VS あり & 南北 & 集約 & なし & - & - & なし \\
\hline $7 \mathrm{vs} 9$ & 分散 & なし VS あり & 南北 & 分散 & なし & - & - & なし \\
\hline $8 \mathrm{vs} 10$ & 集約(中) & なし VS あり & 南北 & 分散 & なし & - & - & あり \\
\hline
\end{tabular}

表 6 机の向き（南北軸と東西軸）の感度解析結果

\begin{tabular}{|c|c|c|c|c|c|c|c|c|c|}
\hline $\begin{array}{l}\text { case } \\
\text { 比較 }\end{array}$ & コピー & 雁行 & 机向き & 会議室 & パーテイション & 主動線 & & 意差 & $\begin{array}{l}\text { インフォーマルコミュニケー } \\
\text { ション回数が多かった方 }\end{array}$ \\
\hline $1 \mathrm{vs} 5$ & 分散 & なし & 南北 VS 東西 & 集約 & なし & - & \begin{tabular}{|l|} 
有 \\
\end{tabular} & $p=0.036$ & 南北 \\
\hline $2 \mathrm{vs} 6$ & 集約(中) & なし & 南北 VS 東西 & 集約 & なし & - & \begin{tabular}{|l|} 
有 \\
\end{tabular} & $p<0.001$ & 南北 \\
\hline $7 \mathrm{vs} 11$ & 分散 & なし & 南北 VS 東西 & 分散 & なし & - & & - & 南北 \\
\hline $8 \mathrm{vs} 12$ & 集約(中) & なし & 南北 VS 東西 & 分散 & なし & - & \begin{tabular}{|l|} 
有 \\
\end{tabular} & $p=0.002$ & 南北 \\
\hline $13 v s 15$ & 集約(北) & なし & 南北 VS 東西 & 集約 & なし & - & & - & 東西 \\
\hline $14 \mathrm{vs} 16$ & 集約(南) & なし & 南北 VS 東西 & 集約 & なし & - & \begin{tabular}{|l|} 
有 \\
\end{tabular} & $p=0.001$ & 南北 \\
\hline $17 \mathrm{vs} 21$ & 分散 & なし & 南北 VS 東西 & 集約 & あり & 室中央 & 有 & $p<0.001$ & 東西 \\
\hline $18 \mathrm{vs} 22$ & 集約(中) & なし & 南北 VS 東西 & 集約 & あり & 室中央 & 有 & $p<0.001$ & 東西 \\
\hline $19 v s 23$ & 分散 & なし & 南北 VS 東西 & 集約 & あり & 回廊型 & 有 & $\mathrm{p}=0.034$ & 東西 \\
\hline $20 v s 24$ & 集約 (中) & なし & 南北 VS 東西 & 集約 & あり & 回廊型 & & - & 南北 \\
\hline
\end{tabular}

表 7 会議室の位置（集約と分散）の感度解析結果

\begin{tabular}{|c|c|c|c|c|c|c|c|c|}
\hline $\begin{array}{l}\text { case } \\
\text { 比較 }\end{array}$ & コピー & 雁行 & 机向き & 会議室 & パーテイション & 主動線 & 有意差 & $\begin{array}{l}\text { インフォーマルコミュニケー } \\
\text { ション回数が多かった方 }\end{array}$ \\
\hline 1vs7 & 分散 & なし & 南北 & 集約 VS 分散 & なし & - & $\overline{-}$ & 集約 \\
\hline $2 \mathrm{vs} 8$ & 集約(中) & なし & 南北 & 集約 VS 分散 & なし & - & - & 集約 \\
\hline $3 \mathrm{vs} 9$ & 分散 & あり & 南北 & 集約 VS 分散 & なし & - & - & 集約 \\
\hline $4 \mathrm{vs} 10$ & 集約(中) & あり & 南北 & 集約 VS 分散 & なし & - & - & 同じ \\
\hline $5 \mathrm{vs} 11$ & 分散 & - & 東西 & 集約 VS 分散 & なし & - & - & 分散 \\
\hline $6 \mathrm{vs} 12$ & 集約(中) & $\begin{array}{ll}- \\
\end{array}$ & 東西 & 集約 VS 分散 & なし & - & - & 集約 \\
\hline
\end{tabular}

表 8 パーティションの有無の感度解析結果

\begin{tabular}{|c|c|c|c|c|c|c|c|c|}
\hline $\begin{array}{l}\text { case } \\
\text { 比較 }\end{array}$ & コピー & 雁行 & 机向き & 会議室 & パーティション & 主動線 & 有意差 & $\begin{array}{c}\text { インフォーマルコミュニケー } \\
\text { ション回数が多かった方 }\end{array}$ \\
\hline $1 \mathrm{vs} 17$ & 分散 & なし & 南北 & 集約 & なし VS あり(室中央) & - & $\overline{-}$ & なし \\
\hline $1 \mathrm{vs} 19$ & 分散 & なし & 南北 & 集約 & なし VS あり(回廊型) & - & \begin{tabular}{|l|l|} 
有 & $p<0.001$ \\
\end{tabular} & あり(回廊型) \\
\hline $2 \mathrm{vs} 18$ & 集約(中) & なし & 南北 & 集約 & なし VS あり(室中央) & - & - & なし \\
\hline $2 \mathrm{vs} 20$ & 集約(中) & なし & 南北 & 集約 & なし VS あり(回廊型) & - & \begin{tabular}{|l|l|} 
有 & $p<0.001$ \\
\end{tabular} & あり(回廊型) \\
\hline $5 \mathrm{vs} 21$ & 分散 & - & 東西 & 集約 & なし VS あり(室中央) & - & \begin{tabular}{|l|l|} 
有 & $p<0.001$ \\
\end{tabular} & あり(室中央) \\
\hline $6 \mathrm{vs} 22$ & 集約(中) & $\begin{array}{l}- \\
\end{array}$ & 東西 & 集約 & なし VS あり(室中央) & - & \begin{tabular}{|l|l|} 
有 & $p<0.001$ \\
\end{tabular} & あり(室中央) \\
\hline $5 v s 23$ & 分散 & $\begin{array}{c}- \\
\end{array}$ & 東西 & 集約 & なし VS あり(回廊型) & 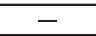 & \begin{tabular}{|l|l|} 
有 & $p<0.001$ \\
\end{tabular} & あり(回廊型) \\
\hline $6 v s 24$ & 集約(中) & - & 東西 & 集約 & なし VS あり(回廊型) & - & \begin{tabular}{|l|l|} 
有 & $p<0.001$ \\
\end{tabular} & あり(回廊型) \\
\hline
\end{tabular}

表 9 主動線（通路の場所）の感度解析結果

\begin{tabular}{|c|c|c|c|c|c|c|c|c|c|}
\hline $\begin{array}{l}\text { case } \\
\text { 比較 }\end{array}$ & コピー & 雁行 & 机向き & 会議室 & パーティション & 主動線 & & 意差 & $\begin{array}{l}\text { インフォーマルコミュニケー } \\
\text { ション回数が多かった方 }\end{array}$ \\
\hline $17 \mathrm{vs} 19$ & 分散 & なし & 南北 & 集約 & あり & 室中央 VS 回廊型 & 有 & $p<0.001$ & 回廊型 \\
\hline $18 \mathrm{vs} 20$ & 集約(中) & なし & 南北 & 集約 & あり & 室中央 VS 回廊型 & 有 & $p<0.001$ & 回廊型 \\
\hline 21 vs23 & 分散 & - & 東西 & 集約 & あり & 室中央 VS 回廊型 & 有 & $p<0.001$ & 回廊型 \\
\hline $22 \mathrm{vs} 24$ & 集約(中) & - & 東西 & 集約 & あり & 室中央 VS 回廊型 & 有 & $p<0.001$ & 回廊型 \\
\hline
\end{tabular}


互作用を表現することが可能である。本研究では、artisoc をベースと して、空間についてはプラン、人については歩行速度、タスクについて は継続時間と発生確率、コミュニケーションについては発生確率を入力 条件としている。なお 1 試行分のフローは次の通り。(1)出勤時刻を正規 分布により決定する。(2)複数のエージェントで行なうミーティングのス ケジュールをランダムに決定する。(3)ミーティング以外のスケジュール をランダムに決定する。(4)タスクの場所が複数ある場合にはランダムに 決定する。これらのランダムに決定するものは、1 試行ごとに乱数によ り生成する。この試行を 15 回繰り返し、その結果の平均を算出する。

注 2） 7 つの Behavior とは、「情報処理」、「収束的思考」、「拡散的思考」、「リ ラックス (休息)」、「リフレッシュ (切替)」、「フォーマルミュ二ケーシ ヨン（予定されていた会議や打合せ）」「「インォーマルコミュニケーシ ヨン（偶発的な雑談や打合せ）」である。

注 3) 密接距離：6〜18 インチ（約 15～45cm）、個体距離：1.5〜4.0 フィート (約 $45 \sim 120 \mathrm{~cm}$ )、社会距離：4.0〜12.0 フィート (約 $120 \sim 360 \mathrm{~cm}) 、$ 公 衆距離：12.0フィート以上（約 $360 \mathrm{~cm}$ 以上）

注 4) 調查対象建物は、一日周期の外部の物理的周期（サーカディアン条件） と人間の生理的な周期が同期していることが自然であり知的生産性にも よいと考え設計し運用している建物であり、外部の自然環境の導入効果 に関する実態調査結果は文献 27 に詳しい。

注 5) 日本建築学会熱シンポジウム（1985）において提案されたオフィス標準 問題 ${ }^{28)}$ 。コアの東西にオフィスがあるため西側フロア $\left(302.58 \mathrm{~m}^{2}(12.3 \mathrm{~m}\right.$ $\times 24.6 \mathrm{~m})$ ) を対象とした。後述の解析ケース（コピー機や会議室の位置、 机のレイアウト等) での感度解析を行なうため、オフィスの建築平面と してはできるだけシンプルな四角形のものを採用した。本オフィスモデ ルは温熱環境の検討だけでなく、吉澤 ${ }^{29)} ら の$ 光環境などにも用いられて いるため、汎用性のあるプランと考え、標準モデルプランに採用した。

\section{参考文献}

1) 沼中秀一 - 高橋祐樹 - 天野健太郎 - 加藤信介 ・高橋幹雄 - 菊池卓郎 : 知的 生産性向上を目指した執務空間におけるコミュニケーションおよび環境要 素に関する実態調査, 日本建築学会環境系論文集 第 80 巻 第 713 号, pp. $609 \sim 619,2015.7$

2) 国土交通省: 知的生産性研究委員会報告書 (平成 24 年度), 2013.3

3) 岡本章伺 : コミュニケーションマネジメントによる知的生産性の向上, 知 的資産創造, 第 7 巻第 1 号, pp. 93 101, 1999.

4) 緑川ゆり・伊香賀俊治・佐藤啓明・割田知裕：オフィスの建築空間とコミ ユニケーションが知的生産性に与える影響, 2010 年度日本建築学会関東支 部研究報告集, pp. 149〜152，2011. 3

5) 谷本潤・萩島理・田中尉貴 : 避難口のボトルネック効果に関するマルチエ 一ジェントシミュレーションと平均場近似に基づく解析, 日本建築学会環 境系論文集 第 74 巻 第 640 号, pp. 753-757, 2009.6

6) 藤岡正樹・石橋健一・梶秀樹・塚越功：津波避難対策のマルチエージェン トモデルによる評価, 日本建築学会計画系論文集 第 562 号, pp. 231-236, 2002. 12

7) 佐野友紀 - 高柳英明 - 木村謙 - 渡辺俊 - 林田和人 ・ 川口和英 - 池田浩敬 · 位寄和久・渡辺仁史：人間行動シミュレーションのための行動データ体系 化, 2003 年度日本建築学会関東支部研究報告集

8) 織田瑞夫・滝澤重志・河村廣・谷明勲 : エージェントモデルによる連続的 空間における人間行動シミュレータの構築, 日本建築学会計画系論文集 第 558 号, pp. 315-322, 2002.8

9) 北上靖大・加藤彰一・谷脇義隆 : マルチエージェントシミュレーションを 用いた学生食堂における環境認識・行動に関する研究, 日本建築学会東海 支部研究報告書 第 45 号, pp. 529〜532，2007.2

10)柴田洋希・加藤彰一: マルチエージェントシミュレーションを用いた学生 食堂のレイアウトに関する研究, 日本建築学会大会学術講演梗概集, E-1, pp. $575 \sim 576,2007.8$

11)木曽久美子・問輝行 : 建築・都市空間における人間行動のモデル化とシ ミュレーション, 日本建築学会計画系論文集 第 76 巻 第 668 号, pp. 1819-1828, 2011. 10

12)木曽久美子・門内輝行 : 人間行動の記号過程の確率ネットワークモデルと それに基づくシミュレーション 建築・都市空間が誘発する人間行動の記 号過程に関する研究, その 2 , 日本建築学会計画系論文集 第 77 巻 第
680 号, pp. 2329-2338，2012.10

13)木曽久美子・門内輝行 : 発話分析に基づく人間行動の記号過程の解読とシ ミュレーション 建築・都市空間が誘発する人間行動の記号過程に関する 研究, その 3, 日本建築学会計画系論文集 第 78 巻 第 687 号, pp. 1003-1012, 2013.5

14）吉井隆・秋元孝之・酒井憲司・富田正裕：オフィス空間における知識創造 の研究, その 1, オフィス空間における執務者行動に関する研究, 日本建 築学会大会学術講演梗概集, D-1, pp. 13-14, 2010.9

15) 富田正裕・秋元孝之・吉井隆・酒井憲司：オフィス空間における知識創造 の研究, その 2 , レイアウト変更による執務者への影響に関する研究手法 の確率, 日本建築学会大会学術講演梗概集, D-1, pp. 15-16, 2010.9

16) 吉井隆・秋元孝之・松浦健太・綿貫安伸・酒井憲司：オフィス空間におけ る知識創造の研究, その 3 , オフィス空間における執務者の行動調査, 日 本建築学会大会学術講演梗概集, D-2, pp. 1137-1138, 2011.8

17) 松浦健太・秋元孝之・綿貫安伸・吉井隆・酒井憲司：オフィス空間におけ る知識創造の研究, その 4 , シミュレーションツールの整合性評価, 日本 建築学会大会学術講演梗概集, D-2, pp. 1139-1140, 2011.8

18) 割田智裕 - 伊香賀俊治 - 林立也 - 佐藤啓明 : 知的生産性に関する研究, そ の 6, CASBEE と連携した知的生産性の経済性評価システムの改良, 日本建 築学会大会学術講演梗概集, 環境工学 I, pp. 97 100, 2011.7

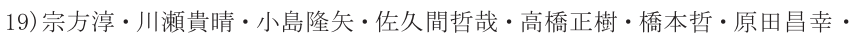
吉井隆 : オフィスビル全体を対象とした知的生産性評価システムに関する 研究, 日本建築学会大会学術講演梗概集, 環境工学 I, pp. 97〜 100, 2012.9 20) 金子弘幸：レーザーセンサーを用いた行動モニタリング調查その 1 才 フィス内のワーカーの活動量比較, 日本建築学会大会学術講演梗概集, 建 築計画, pp. $727 \sim 728,2012.9$

21) 流田麻美 - 樋口美和 - 伊藤光太郎 - 西原直枝 - 田辺新一 ・ 伊藤剛 - 和田克 明・吉野攝津子・間瀬亮平：低炭素化と知的生産性に配慮した最先端オフ イスの調查研究, その 25 , 移転前後オフィスにおける夏季のアンケート調 查およびコミュニケーション調査結果, 日本建築学会大会学術講演梗概集, 環境工学 II , pp. 1391〜 1392, 2012.9

22) 藤田敏郎・谷口元・恒川和久・粐山明久 : オフィスレイアウトの変更によ るワーカーの行動変化に関する研究, 日本建築学会大会学術講演梗概集, 建築計画 I, pp. 191 192, 2003.7

23) 野崎尚子・石川敦雄・樋口祥明：人にやさしい空間 執務空間におけるワ 一カーの行動シミュレーションに関する研究, 日本建築学会大会学術講演 梗概集, 環境工学 II , pp. 1233〜1234, 2012.9

24）株式会社構造計画研究所ホームページ：http://www. kke.co.jp/ (2015. 10.25 参照)

25)エドワード・ホール著, 日高敏隆・佐藤信行訳 : かくれた次元, みすず書 房, 1970.

26)五十嵐貴子・水野里美・松本裕司・仲隆介・山口重之 : ワークプレイスに おけるコミュニケーションに関する研究, その 1, 量的な視点からの活動 把握, 日本建築学会大会学術講演梗概集, E-1, pp. 557-558, 2007.8.

27) 沼中秀一 - 天野健太郎 - 高橋祐樹 - 加藤信介・高橋幹雄 : 知的生産性向上 を目指した執務空間における外部の自然環境の導入効果に関する実態調査, 空気調和衛生工学会論文集 No. 219, pp. 11 22, 2015.6

28) 滝沢博 : 標準問題の提案（オフィス用標準問題），日本建築学会環境工学 委員会熱分科会, 第 15 回熱シンポジウムテキスト, pp. 35-42, 1985.

29) 吉澤望・小林紘一・稻沼 實・武田 仁 : 東京圈における昼光照度基準標準 年気象データ TWD9302/L の昼光照明シミュレーションへの応用, 日本建築 学会環境系論文集 第 598 号, pp. 23 〜 29, 2005. 12

30) 日本建築学会編: 第 3 版コンパクト建築設計資料集成, p. 291, 丸善, 2005. 31) 杉崎 奈緒子 - 加藤信介 - 高橋幹雄 - 沼中秀一 - 天野健太郎 - 菊池卓郎 谷英明・高橋祐樹：インフォーマルコミュニケーションを評価指標とした 行動シミュレーションの感度解析, 日本建築学会大会学術講演梗概集, 環 境工学 I, pp. $117 \sim 118,2015.9$ 


\title{
APPLICATION TO HUMAN BEHAVIOR SIMULATION TO MAKE PREDICTION OF INFORMAL COMMUNICATION BASED ON ANALYSIS OF SURVEY OF COMMUNICATION AND TASK
}

Field survey on communication and workplace environment in an office which is aimed at improving workplace productivity (Part2)

\section{Shuichi NUMANAKA* , Hiroki TAKAHASHI*, Naoko SUGISAKI***, Takuro KIKUCHI*, Shinsuke KATO**, Kentaro AMANO*, Hideaki TANI* and Mikio TAKAHASHI*}

\author{
* Takenaka Corporation \\ ** Prof., Institute of Industrial Science, The University of Tokyo, Dr.Eng. \\ *** SUEP. Co., Ltd./Former Master Course Student, Graduate School of Engineering, The University of Tokyo
}

\begin{abstract}
As a technique for verifying the improvement of workplace productivity, behavioral simulation using the multi-agent model is considered to be effective. The purpose of this study is to obtain a contributing knowledge to the study of the workplace productivity improvement by using human behavior simulation. Performing a sensitivity analysis about informal communication can be considered to be meaningful. In this study, analysis tool that simulates the behavior of workers intended for office space has been constructed using artisoc was used. Preliminary calculations were made by the office layout in the actual building. Survey of this building was analysed. The largest amount of informal communication was between sitter and migrant by survey analysis. The amount of informal communication of per person per day between sitter and migrant and between migrant and migrant was $0.75 \mathrm{~h}$. Office layout in this actual building was a galleried corridor type. Sensitivity analysis in the standard model plan has been made. Sensitivity analysis target is as follows. Position of the copy machine, the orientation of the desk, the location of the meeting room, the presence or absence of the partition, such as the corridor type of sensitivity.

This study was obtained the following knowledge. The number of occurrences of informal communication was greater in the case of a galleried corridor type. The cases that copy machine are aggregated in the office floor, it was less the number of occurrences of informal communication. The location of two copy machines were compared aggregate position with segregate, therefore informal communication amount of the segregate position were more often than that of the aggregate. If the movement amount of the agent is increased, it will be suggested to contribute to an increase in informal communication amount.
\end{abstract}

